\title{
"He may exalt you at the expected time" (1 Pet 5:6). The Conception of Time in the First Letter of Peter
}

\section{STANIS ŁAW HAŁAS}

The Pontifical University of John Paul II in Cracow, Poland

stanha@poczta.onet.pl, ORCID: 0000-0001-6660-9757

\begin{abstract}
In the First Letter of St. Peter we find a clear temporal direction toward a final reward, which will be a divine exaltation and appreciation. Its time is always specified as кaıpó, as a concrete moment, a point in time. Otherwise хрóvoৎ, as durative time, always specifies the time of earthly existence, especially from the beginning of Christian life. It is directed toward the final and definitive кaıpóc. This temporal direction is especially visible in many terms with the preposition ciç, as hope, heritage in heaven, salvation, exaltation, appreciation, light, and the glory of God. These are especially frequent in the initial part of the Petrine Letter. ion, light and the glory of God. They are especially frequent in the initial part of the Petrine Letter.
\end{abstract}

Keywords: time, кaıрóৎ, хрóvoৎ

The conception of time in the First Letter of Peter has not yet been analysed in a separate book publication or a scientific article addressing this issue. However, attention has been drawn to it occasionally, especially in the comments made to the whole Letter. ${ }^{1}$ David G Horell's and Wei Hsien Wan's evaluation on the matter of the connection of time with eschatology and Christology in this particular letter, which was published in the year of 2016, constitutes an article which touches on the subject of time in the First Letter of Peter. ${ }^{2}$ There are a few publications on the concept of time in the Bible and its individual collections. In the Polish language for instance, there are very interesting and insightful studies on the subject of the kaıpóc Christian time in the Letters of Paul. They were published by late Stanisław Bielecki. ${ }^{3}$ However, it turns out that the conception of time in the First Letter of Peter has been especially emphasised and certainly deserves a more thorough exegetical analysis.

E.g. Elliott, 1 Peter, 338.

Horell - Wan, „Christology," 263-276.

Bielecki, Kaıpós (1996) and a more popular edition: Bielecki, Chrześsijanin (1999). 


\section{Kaıpós as the Time of Final Exaltation}

The sentence from the First Letter of Peter quoted in the title does not carry any additional determination of time in the Greek original and literally speaks of the ex-

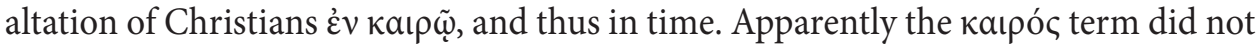
need an additional word in the biblical Greek language in order to be known what time was spoken about. It is different in all of the translations of this phrase, starting with Latin Vulgate, which had to add a term that specified the time, namely tempus visitationis, the right time (translation of Paul's Edition), tempo opportuno (CEI), proper time (New American Standard Bible). The others translate kaıpó moment (BT and Warszawsko-Praska Bible) or moment fixé (TOB).

These divergences alone signal the specificity of the Greek kaıpó, , which does not precisely correspond with our contemporary determinations of time. Already mentioned S. Bielecki, in his monograph entitled Christian Kaıpós in the light of the Letters of St. Paul, paid attention to the fact that the initial sense of this term was the proper measure or restraint, and only later more or less in the classical era, it gained the meaning of the right time, a convenient memento to do or to achieve something. Kaıpós began to mean the favourable time or circumstance. ${ }^{4}$

The same author noticed, in his dissertation, the specificity of Paul's approach to the kaıpó term, which has been already expressed in the title. It is primarily about the Christian kaıpó , which is one's opportunity, offered by God, to receive Christ's Redemption. For him, it is the time of God's love and kindness (cf. Rom 3:26), since Christ died for human sins (Rom 5:6). Therefore, the opportunity given by God should be properly used for one's own salvation (Rom 13:11), even if it is marked by current adversities and suffering (Rom 8:18). ${ }^{5}$

Analysing the concept of time in the Pauline Epistles, S. Bielecki noticed and signalised a different specificity of the kaıpó concept in the First Letter of Peter. ${ }^{6}$ In our study, we will try to answer what it actually is. A very strongly marked orientation of the Christian life towards salvation, which will manifest itself in the last time:

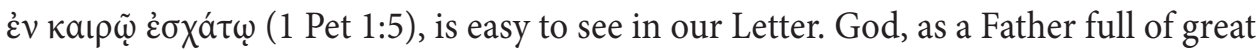
love ${ }^{7}$ gave Christians a new life thanks to the resurrection of his Son. The author of the First Letter of Peter directly says that God has begotten the Christians again

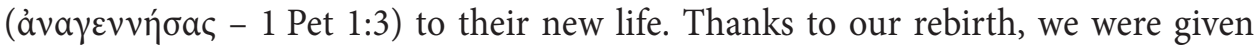
some kind of an embryo of a new life, which manifests itself in living hope: $\dot{\varepsilon} \lambda \pi$ í $\zeta \tilde{\omega} \sigma \alpha$. This hope, in turn, directs us to achieve a great heritage in heaven and this will be the salvation that will occur at the final moment in time. Hope, by its very nature,

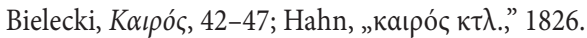

Bielecki, Kaıрóৎ, 221-222.407-408.

Bielecki, Kaıюó, 105.402.

Hałas, Pierwszy List św. Piotra, 79-81.
} 
directs human desires to a particular goal in the future. This direction is highly enhanced by means of a series of terms preceded by the preposition cic:

$\varepsilon \dot{\varepsilon} \varsigma \dot{\varepsilon} \lambda \pi \hat{i} \delta \alpha \zeta \tilde{\omega} \sigma \alpha v$ (= towards living hope - 1 Pet 1:3),

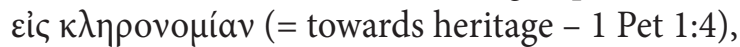

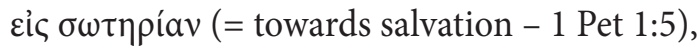

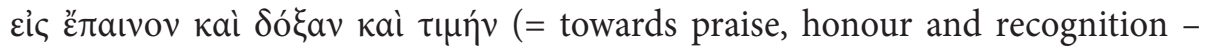
1 Pet 1:7).

All of these values will become the part of Christians $\dot{\varepsilon} v$ kaıp $\tilde{\omega}$, and thus during the time of final happiness. Therefore kaıpó constitutes, for the author of the First Letter of Peter, an especially awaited and desired moment of God's reward. It is already guaranteed for Christians, if only they will not destroy it with their demeanour. Thanks to the new birth, they were directed towards its achievement precisely at the expected time point referred to as kaıpóc. It was defined using this Greek noun in accordance with its specificity of meaning. It determines a point in time, i.e. a particular moment, unlike $\chi \rho o ́ v o \varsigma$, which defines linear time, i.e. duration in a specified time period. ${ }^{8}$

Within the meaning of the First Letter of Peter, kaıpó of Christians' exaltation, their spectacular triumph and definite reward. Its most important term is $\kappa \lambda \eta \rho о v o \mu i ́ a$, translated as legacy. It was emphasised and described with the use of three adjectives starting with ả-privativum:

ä $\varphi$ Ө $а \rho \tau о \varsigma$,

кaì ảuíavtos,

кaì ảuápavtoc.

They stress its indestructibility and durability. The last of the three terms, namely ảuápavtoc, may describe for instance, a non-wilting flower, which does not lose its freshness and does not fade over time. Thus, it indicates the full durability of the re-

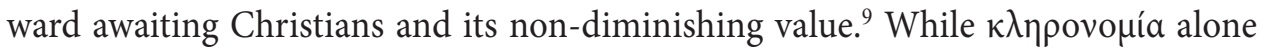
is, in the biblical tradition, firstly the definition of the Promised Land given to the Covenant people as an inalienable property, (e.g. Gen 15:7 n; Exod 15:17; 23:10; Deut 1:8 etc.), and then, in the books of the New Testament, as a new Promised Land in the form of a homeland in heaven (cf. Matt 19:29; 25, 34; Mark 10:17 etc.). Unlike our contemporary understanding of heritage, it does not necessarily stand for goods lawfully inherited after parents, or on the basis of a last will. As Hebrew prototypes indicate, the biblical term especially indicates the full and inalienable nature of owning something, in our case a reward that Christians will receive in the expected kaıpóc. A logical connection between new birth and God as a Father

Cf. e.g. Elliott, 1 Peter, 338.

Broader discussion in: Hałas, Pierwszy List św. Piotra, 81. That is why some translate it as a never-ending heritage (BT ${ }^{5}$, French TOB). 
may also be noticed in our Letter. ${ }^{10}$ Additionally, this heritage is guaranteed, as if it were looked after by armed guards ( $\tau \varepsilon \tau \eta \rho \eta \mu \varepsilon ́ v \eta)$. Similarly, Christians are protected

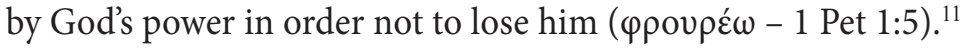

A little further in line 7, this reward has also been described triply as हैं $\delta \delta^{\prime} \xi \alpha$ and $\tau \mu \eta$. The first noun means, in accordance with its etymology, praise or praising someone. The remaining two carry a similar sense and also indicate the recognition of God for honouring Christians for their life attitude. Whereas the appreciation from God, will become a compensation for them for the moral humiliation they get from the pagan community for their beliefs. It turns out that the author of the First Letter of Peter strongly emphasises the value understood in the sense of moral approval and recognition, as can be seen through the frequent use of the vo-

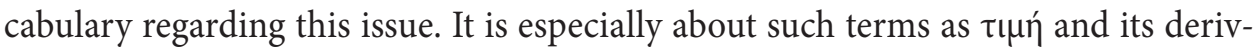

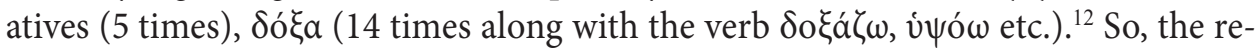
ward anticipated by the Christians will consist not so much of receiving something very expensive, but above all, of recognising and exalting those who have suffered from humiliation and alienation of the pagan community. Salvation, in the understanding of the author of the Letter (1:5.9.10;2:2) will be based primarily on God's appreciation. It will become the share of the Christians in the anticipated point in time defined as kaıpóc.

At the end of our Letter, God's reward has been clearly defined as exaltation: "He

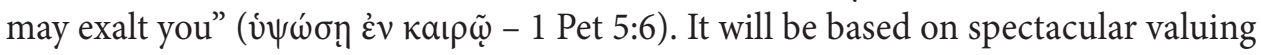
the Christians against those who humiliated and despised them. In this way, they will receive compensation for alienation and marginalisation on the part of the demoralised society (cf. 1 Pet 4:3 n), in which they had to live. Therefore, they should not seek human favours and vain glory but trust God and rely on his dependable

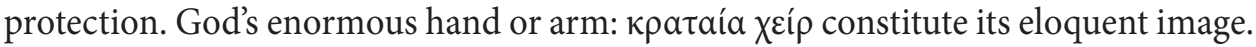
The author of the Letter refers to the well-known Yahweh power symbol, which liberated the Israelites from Egyptian slavery with his "mighty hand" (cf. Exod 13:14.16, etc.). Therefore, Christians should put their full trust in God's power, as if humbling themselves in the shadow of His mighty hand, in order to deserve his exaltation even more.

Having hope for God's exaltation $\dot{\varepsilon} v$ kaı selves in relation to others but instead they should adopt a submissive attitude. They should not search for passing glory and recognition in the eyes of people, which usually leads to unnecessary competition and discord. Resignation from a claiming attitude does not apply solely to living in a Christian community and family (cf. útotá $\sigma \sigma \omega-3: 1.5$ ). It should also be manifested in obedience towards the Chris-

\footnotetext{
Cf. Godlewska, Cierpiał, 138-139.

Hałas, Pierwszy List św. Piotra, 81-82.

Broader discussion in: Hałas, Pierwszy List św. Piotra, 87-88.
} 



the people (2:13), even if it does not favour the Christians. They are even encouraged to obey their patrons and owners, also those strict and ruthless ones (2:18). The final exaltation $\dot{\varepsilon} v$ kal $\rho \tilde{\omega}$ will become their compensation and reward for their attitude of subordination and resignation from unnecessary claims.

The term kaipó of the beginning of God's judgment. The anticipated judgment will bring a due and strict punishment for all the evil that is happening in the world, in order to save those unjustly humiliated and suffering. For the righteous, it will become the end of suffering, and therefore rescue and salvation: "the righteous will come to salvation" ( $\sigma \omega \dot{\omega} \zeta \varepsilon \tau a \mathrm{l}-1.18)$. The usage of this term in the context of God's judgment confirms its connection with the final exaltation and the reward for the believers. It is actually about the same point in time of God's intervention in human history, with the purpose of restoring justice and rewarding those who had to suffer as a result of unjust treatment and rejection.

This very much anticipated moment in time has also been defined as the mo-

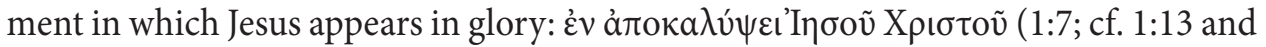
4:13). Thus, the final manifestation of the glorified Jesus will also be the manifestation, salvation and reward for the Christians, as seen in the words about salvation

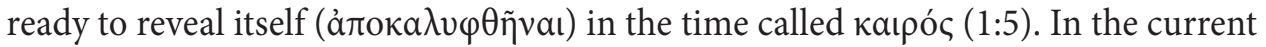
duration of time, it has only begun and is as if in the bud, while in the expected katpóc

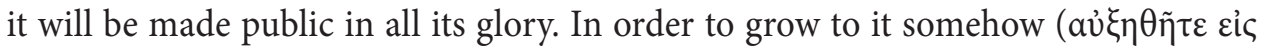
$\sigma \omega \tau \eta i^{\alpha} \alpha$ - 2:2) we were reborn again to hope (1:3) and we should long for the word of God just like newborn babies desire and need their mother's milk.

In the risen Jesus, exaltation and glory, which have already been seen, will become the participation of the Christians in the anticipated time: $\dot{\varepsilon} v$ kaı $\rho \tilde{\omega}$. Just like in His life after the time of suffering and rejection, came the time for exaltation and worship, the same will happen to the lives of the Christians at the time of His glory $(1: 11.21 ; 4: 13 ; 5: 1)$.

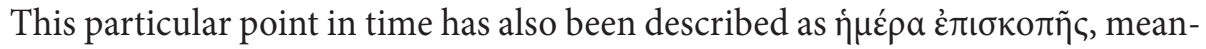
ing the day of the haunting (2:12). It is about the specifically designated time of God's arrival for the final judgment and the reward for the saved. The day also belongs to the point time determinations, similarly to kaıpó

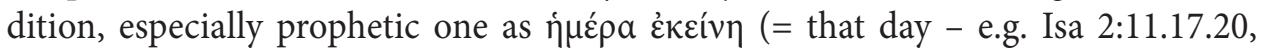
etc.). Then, God will spectacularly intervene in the history of the broken world and will make a judgement in order to save His believers. Therefore, in our Letter, it is

13 The term $\pi \rho \varepsilon \sigma \beta v \tau \varepsilon$ é refers not only to the seniority, in the sense of a higher age (as the opposite of $v \varepsilon \omega \dot{\tau} \tau \rho \rho \iota)$, but first of all to the authority of the authorities in the Christian community. Hence the definition of Christian priests as presbyters. 
the same as kaipóc, since it indicates the same awaited point in time of the final salvation, exaltation and reward.

The guarantee of final exaltation and reward should already be the reason for Christian joy and optimism that in the expected kaıpó undisrupted by any unpleasantness: "so that you my bee full of joy when his glory is revealed" (4:13). The reason for it will be the reward and exaltation expected in the time of kaıpóc. Thus, it is about a very desired and expected moment in time, in the direction of which all the present time of Christian life is oriented. So, кaıpós in the First Letter of Peter, is a very desired and awaited moment of happiness, in which all the hope and expectations, of the Christians struggling with opposites and annoyances of everyday life, will be fulfilled. Their life is very much focused on this happiest moment, which will become the coronation and fulfilment of the expected reward from God. This direction is so strong in our Letter that one can speak as if about a tension of time currently being lived towards the desired moment of fulfilment.

This powerful time orientation, emphasised by the frequent use of terms with the preposition $\varepsilon i \varsigma$, finds its continuation also in other parts of our Letter. It can be seen in the efforts of ancient prophets to be able to explore Christ's kaıpó the time of His suffering and worship: "trying to determine the time and setting"

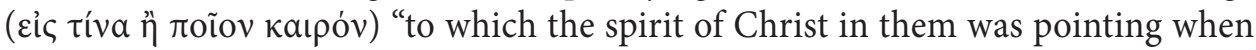
He predicted the sufferings of Christ and the glories to follow" (1:11). It is the se-

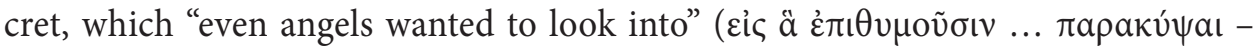
1:12). Whereas in 1 Pet 2:22 it is told about the rising of Christians towards salvation (zic $\sigma \omega \tau \eta \rho i ́ a v)$. It is also said a few times about the vocation of Christians to

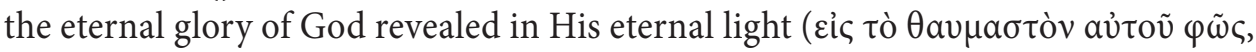

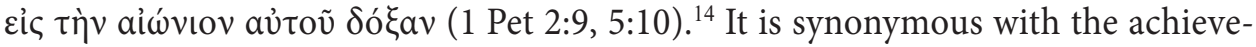

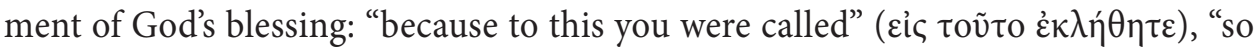
that you may inherit a blessing" - 3:7. The blessing is also a sign of recognition and approval from God. It is significant that the receipt of God's blessing was defined by the verb $\kappa \lambda \eta \rho о v o \mu \varepsilon \dot{\varepsilon} \omega$, which corresponds with the definition of God's reward

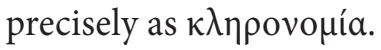


can also be seen in the initial orientation of Christian morality on obedience and redemption: "sanctified by the Spirit of obedience to Jesus Christ and sprinkling by

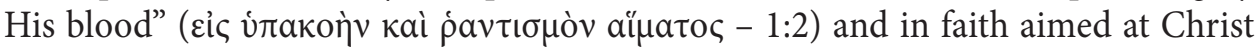
( ble in the Christians' effort to achieve unrelenting brotherly love in the community ( $\varepsilon i \varsigma \varphi \varphi \lambda \alpha \delta \varepsilon \lambda \varphi i ́ a v-1: 22$ ), and also in the engagement in the construction of a new 


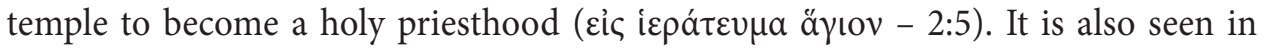

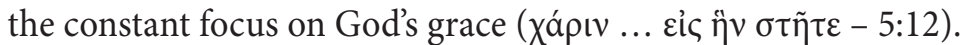

In contrast to the Pauline Letters, the First Letter of Peter does not portray kaıpó as the present time of offered salvation. It is not about the appearing or the only chance to achieve salvation, but about the destination point of Christian existence. It is highly expected and desired, while the whole present is strongly oriented towards the moment in time of the final fulfilment and happiness.

\section{Xpóvoc as the Time of Temporal Struggles}

However, the time of current Christian existence is no longer described as kaıpó ৎ in

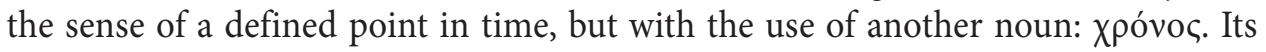
semantic specificity is the time extension, and thus the duration of time. ${ }^{15}$ What is interesting, this term also appears in our Letter four times (1:17.20; $4: 2 \mathrm{n})$, similarly to the term kaıpóc. Let's take a closer look at its specificity in order to see the seman-

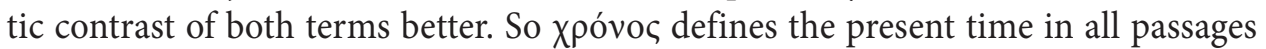
of the First Letter of Peter. In 1:17 it is the time spent as if in foreign land or exile: rapoikía. In the context of our Letter, it is about the alienation of the recipients by an unfriendly or hostile pagan environment and about their social marginalisation, and not in the sense that all earthly life is a time of exile in relation to the expected


able time which nevertheless must be lived with due respect given to God and His call to holiness, or high moral perfection. ${ }^{17}$ In this sense, one should understand the call to moral conduct $\dot{\varepsilon} \vee \varphi o ́ \beta \omega$ (1:17), which is the biblical fear of God. It is by no means the fear of God, who is after all defined as the Father, but instead the respect and appreciation for His will. ${ }^{18}$

The time of earthly life, both before the conversion to Christianity as well as the already consciously lived Christian life were described with the use of the same

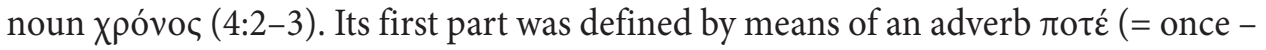
1 Pet 3:20) as a past period of pagan life. It was characterised with decay typical for this kind of environment. It manifested itself in promiscuity, succumb to lust, drunkenness, revelry and idolatry (c. 3). Thus, it is about moral corruption manifested primarily in alcoholism and promiscuity, which was apparently a characteristic feature of the pagan society of that time.

15 Cf. even Popowski's dictionary (Wielki stownik grecko-polski Nowego Testamentu), under the term.

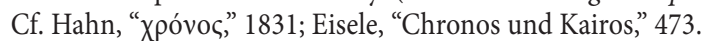

16 Cf. Elliott, A Home for the Homeless, 37-40; Hałas, Pierwszy List św. Piotra, 110-111.

17 Godlewska, Cierpiał, especially from p. 211.

18 Broader discussion in: Hałas, Pierwszy List św. Piotra, 110. 
However, the current experience of the Christian ideal should be completely different and be guided not by any evil desires but instead by God's will. Another adverb vข̃v points to it in our Letter, it indicates the already Christian present, in contrast with the pagan past: $\pi$ orर́ (1 Pet 1:12; 2:10.25; 3:21). Horell and Wei Hsien Wan see, in such a time structuring, a delicate allusion to the emperor's birthday celebrated in the pagan environment as the time determinant. Although for Christians, it is not the emperor but Christ who is the determinant of the Christian time. ${ }^{19}$

It is interesting that the time of the revelation of Jesus Christ has also been defined, though in a more general way, by means of the noun $\chi \rho o ́ v o c$. For it is

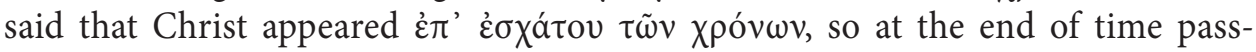

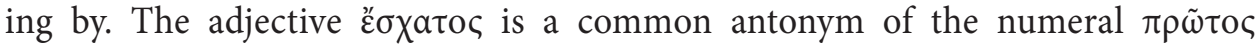
(e.g. 2 Pet 2:20; Rev 1:17 etc.) and indicates its reverse, and therefore something last. The phrase used by the author of the First Letter of Peter means that Christ appeared in the world at the end of $\chi \rho$ óvol, so earthly times in plural. This time corresponds with the past pagan times, which 1 Pet 4:3 also mentions. The coming of Christ put an end to the first stage of $\chi$ póvo $\varsigma$ and began its second part, which is clearly aimed at definite kaıpóc.

The conceptual precision of the author of our Letter, who clearly distinguishes

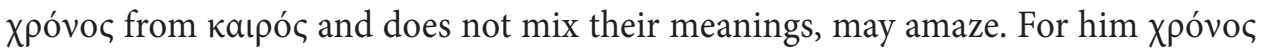
is always the term standing for the passing of earthly time, both before and after the coming of Christ. It is always, and especially since the resurrection of Christ, strongly targeted, as if it were strained towards kaıpó $\varsigma$, which always sets the expected time point for definitive happiness of Christians.

This kind of conceptual precision is impossible to express in translations into other languages, both contemporary ones and Latin. All of them generally have one time specification: tempus, tempo, temps, tiempo, time, Zeit and they use it both as an equiv-

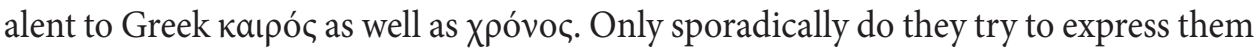
by means of other counterparts, such as momento (1 Pet 4:17; 5:6 - CEI, TOB), time (1 Pet 4:17 - Saint Paul's Bible), or not very successful moment (1 Pet 1:11; 5:6 - BT ${ }^{5}$ ). Sometimes, they use more descriptive equivalents, such as in 1 Pet 5:6: tempus visitationis (Vulgate), the right moment in $\mathrm{BT}^{5}$, proper time in the Pauline Bible, proper time in English translations, tempo opportuno, moment fixé. However, we will not find in them such a consistency in distinguishing the two Greek terms, one of which means the passing of life in the anticipation of final happiness, while the other precisely determines the expected time point of this happiness.

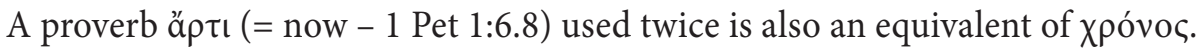
It determines the present time of enduring distress as a trial that refines and perfects Christian faith. ${ }^{20}$ This faith was compared to precious gold, which is smelted on

19 Horell - Wan, „Christology,” 270-271.

20 Cf. Troy, “The Present Indicative," 308-309. 
fire in order to purify and refine it. Similarly, the Christian faith needs purifying in the experiences of the everyday life. Faith is the basic term for a Christian's relationship with Christ (1:8) and God (1:21), which strengthens him during his mortal life

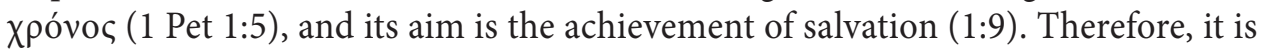

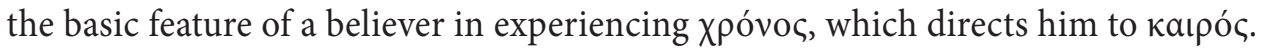

\section{Conclusions}

The analysis of the content of the First Letter of Peter in the context of time shows that the author of the Letter is indeed interested in this matter. He uses two Greek definitions of time relatively often, for four times both the term kaıpó

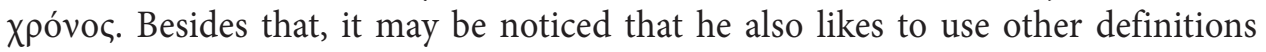

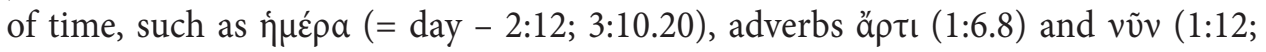
$2: 10.25 ; 3: 21)$ indicating the present, and the adjective है $\sigma \chi \alpha \tau o \varsigma$ (1:5.20), indicting the finality.

Consequently, he makes the difference between $\chi \rho o ́ v o \varsigma$, as a definition of continuous and linear time, and kaıpó orientation of the Letter aims exactly at kaıpóc as a highly expected and desired, by the recipients of the Letter, moment in which they should expect the magnificent reward in the form of appreciation, recognition and exaltation provided by God. In the direction of the final reward, the whole Christian hope (1:3.13.21; 3:5.15), initiated by God, as if a new birth, is oriented towards the final reward. The hope for achieving the expected reward from God motivates their Christian attitude and dignity, which is expressed in giving up exorbitant claims against the environment that could harm a sense of brotherhood and their Christian image.

Thus, the time in the First Letter of Peter is highly oriented towards the final кaıpó, which is the awaited and coveted moment of God's final distinction and reward. This orientation is emphasised, for instance, through the multiple usage of terms preceded by the preposition $\varepsilon i \varsigma$, which indicate the reward expected in

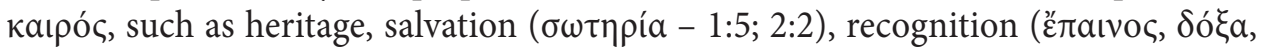

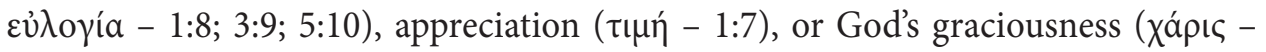
$1: 10 ; 5: 12$ ). This dynamic orientation towards kaıpó can be graphically depicted in the following way:

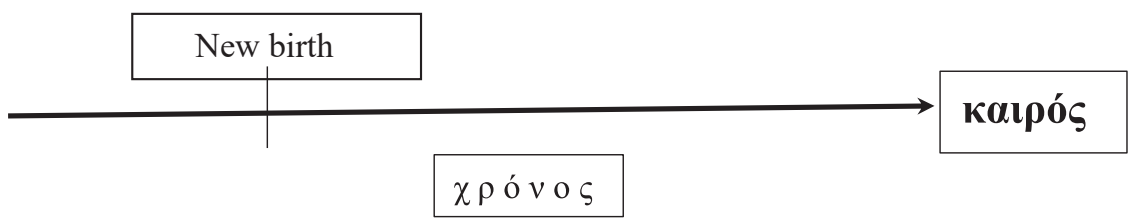


STANISŁAW HAŁAS

\section{Bibliography}

Bielecki, S., Chrześcijanin i czas według listów św. Pawła (Jak Rozumieć Pismo Święte 11; Lublin: RW KUL 1999).

Bielecki, S., Kaıpó chrześcijanina w ujęciu listów św. Pawła (Lublin: RW KUL 1996).

Eisele, W., „Chronos und Kairos. Zum soteriologischen Verhältnis von Zeit und Ewigkeit in den Pastoralbriefen," Early Christainity 3 (2012) 468-491.

Elliott, J.H., 1 Peter. A New Translation with Introduction and Commentary (The Anchor Bible 37 B; New York: Doubleday 2000).

Elliott, J.H., A Home for the Homeless. A Social-Scientific Criticism of 1 Peter. Its Situation and Strategy, With a New Introduction (Minneapolis, MN: Fortress 1990).

Godlewska, A.F., Cierpiał i zostawił wam wzór. Wysoki ideał moralny według 1 P (Warszawa: Fundacja Żywe Słowo - Polska Prowincja Pasjonistów 2017).

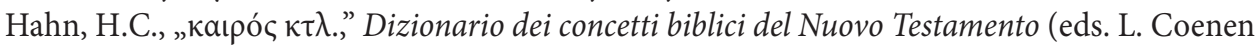
et al.) (Bologna: EDB 1976) 1826-1831.

Hahn, H.C., „Хৎóvoc,” Dizionario dei concetti biblici del Nuovo Testamento (eds. L. Coenen et al.) (Bologna: EDB 1976) 1831-1836.

Hałas, S., Pierwszy List św. Piotra. Wstęp - przekład z oryginału - komentarz (Nowy Komentarz Biblijny. Nowy Testament 17; Częstochowa: Edycja Świętego Pawła 2007).

Horell, D.G. - Wan, Wei Hsien, „Christology, Eschatology and the Politics of Time in I Peter, Journal for the Study of the New Testament 38/3 (2016) 263-276.

Popowski, R., Wielki słownik grecko-polski Nowego Testamentu, 2 ed. (Warszawa: Vocatio 1995).

Troy, M., „The Present Indicative in the Eschatological Statements of 1 Peter 1:6.8, Journal of Biblical Literature 111 (1992) 307-312. 